\title{
MEANINGS IN LITERATURE
}

\author{
Andarwati
}

Ketua Program Khusus Pengembangan Bahasa Inggris (PKPBI)

Dosen Jurusan Bahasa dan Sastra Inggris

Fakultas Humaniora dan Budaya, Universitas Islam Negeri (UIN) Malang.

Jalan Gajayana No. 50 Telepon (0341) 570872, Faksimile (0341) 570872 Malang 65144.

\begin{abstract}
Abstrak
Penggunaan Bahasa harus memiliki hubungan dengan dunia luar. Hubungan tersebut berkaitan dengan maknanya. Makna dalam karya sastra berarti intensi yang dimiliki penulis/pengarang karya sastra tersebut. Ada dua makna di dalam karya sastra yaitu (1) makna total yaitu pengalaman bagaimana karya sastra tersebut dikomunikasikan; dan (2) makna prosa yaitu model ekspresi dari pengalaman tersebut. Bahasa dalam karya sastra sangat multidimensional di mana ia terdiri dari kata-kata yang memiliki multi makna: denotatif dan konotatif.
\end{abstract}

\section{Kata Kunci}

Makna, Sastra, Multidimensional, Denotatif, Konotatif

\section{Introduction}

Practical use of language must convey information which is understood universally. This comprehension is what is termed "the meaning" of language (Blinger \& sears, 1981). By definition a language is a set or series of signs and symbols which have meaning (Cooper, 1973), and therefore the fundamentals of meaning must exist before any set or series of signs can be defined as a language. In other words, without meaning there can be no language, which prime evidence of the importance of "meaning" in communication. 
Meaning however can be ambigious, especially when a reader or listener is trying to interpret the message contained and purveyed by literature such as poetry, prose fiction or for that matter drama. This gives students, researchers and critics of literature a problem since the question as to whether the meaning is "literal" or "literary"must be addressed and answered. In oerder to address and answer the paradigm presented by the word "meaning" as it applies to literature, the following literary examples are presented, discussed and analysed.

\section{The Different meanings of "meaning" in literature}

To have a clear description about the meanings of meaning in literary use is by contrasting them with its meanings in practical use.

The term "meaning" in practical use is defined by Odgen and Richard (1930) in twenty one different ways. According to them, meaning in its use can refer to either one of (1) an intrinsic property, (2) a unique analyzable relation to other things, (3) the other words annexed to a word in the dictionary, (4) the connotation of a word, (5) an essence, (6) an activity projected to an object, (7) an event intended, (8) the place of any one or anything in a system, (9) the practical consequences of a thing in our future experience, (10) the theoretical consequences involved in or implied by a statement, (12) emotion arouse by anything, (13) that which is actually related to assign by a chosen relation, (14) the mnemonic effects of a stimulus, (15) some other occurrence to which the mnemonic effects of any occurrence are appropriate, (16) that which a sign is interpreted as being of, (17) that to which the user of a symbol actually refers, (18) that to which the user of a symbol ought to be referring, (19) that to which the user believes himself to be referring, (20) that what the interpreter of a symbol refers, believes, himself and the user to be referring, and (21) a volition or intention, such as that in a poetry line. Whichever definition an expression refers to, meaning in scientific use lies in semantic representation found in phonemic representation of a language. 
The last definition of meaning given by Odgen and Richard (1930) above is relevant with the meaning of "meaning" in literature area, that is a volition or intention owned by the author or writer of literary work. Through an analytical approach we are able to grasp the ideas the writer or author express including both his central insight, which becomes the theme of the work, and the detailed ideas found in every selected words, phrases, or sentences reflected through the dictions of the work.

Dealing with the contents of various kinds of literary works, there are two kinds of meanings: (1) the total or literary meaning, and (2) the prose or litered meaning. The total meaning of poetry means the experience it expresses (Perrine, 1984). It refers to the entire experience related in the poem starting from the sentiments presented in the first line of the first stanza until that expressed in the last line of the last stanza. The other hand, the total meaning of a short story means the total experience in the event or situation told in the writing starting from that told in the first sentence of the first paragraph until the last sentence of the last paragraph. Also the total meaning of drama means the total meaning it expresses through all of the events and situations with their own atmosphere expressed dominantly through the characters' dialogues starting from the first dialogue in the first scene until the last dialogue of the last scene.

The prose meaning of literary work is not necessarily concerned with an idea. It refers to the mode of expression of the sentiment it communicates. It may be a story, a description of human character, a statement of emotion, or some combinations of them.

A "Little Jack Horner' poem below may clarify the ideas of meanings I have discussed. This poem is simple; it has only one stanza consisting of six lines. Its language is also simple. After we read it we know that the total meaning of the poem is the total experience, told in all lines of its stanza, of being a good boy. The total experience of this poem consists of that of (1) how and where little jack Horner sits, (2) what and how he is eating, etc., that makes him feel as being a good boy. 
The prose meaning of the poem is a description of human character of little Jack Horner.

\title{
Little Jack Horner
}

\author{
Little Jack Horner
}

Sat in a corner

Eating a Christmas pie.

He stuck in his thumb

And pulled out a plum

And said, "What a good boy am I"

\section{Anonymous}

Another poem warthy of discussion is "Meeting at Night", written by Robert Browning.

\section{Meeting at Night}

The grey sea and the long black land;

And the yellow half-moon large and low;

And the startled little waves that leap

In fiery ringlets from their sleep

As I gain the cove with pushing prow,

And quench its speed $i^{\prime}$ the slushy sand

Then a mile of warm sea-scented beach;

Three fields to cross till a farm appears;

A tap at the pane, the quick sharp scratch

And blue spurt of a lighted match,

A voiceless loud, through its joys and fears,

Than the two hearts beating each to each! 
(Robert Browning (1812-1889)

This "Meeting at Night" poem consists of two stanzas. It is a poem about love. The total meaning of this poem is the experience of being in love it communicates. Words in all lines of the poem (from the first line of the first stanza until the last line of the last stanza) expressed sentiments about a sweet and exciting love experience. From this analysis we can come to terms with some major ideas: (1) When one is in love everything seems beautiful, (2) When one is in love trivial things done or happening are significant, (3) When one is in love every thing he/she sees, hears, smells, touches are memoreble. The prose meaning of the poem is a combination between a story and a statement of feeling.

Analyzing the short story below will be further help in developing a clear understanding of the two different meanings in literary work.

\section{Farmer and Sons}

There was once an old farmer who had worked all his life growing grapes in his vineyard. He had done very well for his wife and their three sons. But at last, it was near the time when he would die, and he wanted to teach his sons how to be good farmers. He wasn't all sure that they really knew how important it is to work hard. So he called them into him one evening and said:

"My boys, it may be that I haven't much longer to live. But before I die, I want you to know that there is great treasure in my vineyard. Promise me you will remember that when I am gone".

The three young men promised; and not long after that, their father died. Then they remembered what he had said, and began to look for the treasure he had left them in the vineyard. They pictured in their minds much coins, or silver plate, or things of that sort. How hard they worked in the hot sun, digging around the vines, 
turning over the soil with fork and spade, or going over every inch of ground with a hoe.

Well, the three brothers spent a month at least turning over the soil in that vineyard, but not so much as a penny piece could they find. At last they gave up, thinking their father must have been wandering in his mind. But soon the grapes began to appear, and although it was not a good year for other farmers, their grapes were bigger than any that had been grown before in that part of the country. When the grapes were ripe, how big and juicy they were! The brothers took them to the market, and were amazed at the high price they fetched. So now they understood what their father had meant by the great treasure he had left them in the vineyard. They saw that all their hard work had not been wasted, for it had made the grapes grow as they had never grown before.

By James Reeves

The story seems to convey the writer's central hypothesis that hard work brings prosperity. The total meaning of this story is this sentiment it communicates through every event and situation told from the first sentence of the first paragraph until that told in the last sentence of the last paragraph. The major things of the sentiments it expresses are: (1) being an old grape farmer who was a husband and a father of three sons who were not accustomed to work hard, (2) trying to teach sons to be good farmers, (3) making the sons realize of the importance of hard work, and (4) achieving a successful outcome regarding educating sons to be prosperous farmers. Its prose meaning is a combination between a story and a description of human character.

\section{Denotation and Connotation Meanings}

Most words in literary work have two kinds of meanings: denotation (literal) and connotation (literal). Denotation meaning is the dictionary meaning of a word. The word "company", for example, has five meanings in Oxford Advanced Learner's Dictionary: (1) being 
together with another or others, (2) group of people together, (3) group of people united for business or commercial purposes, (4) group of people working together, and (5) subdivision of an infantry battalion, usually commanded by a captain or a major. This variety of denotation is a feature of most lexical listing.

The connotation or hidden meaning of a word is what it suggests behind what it expresses. It is acquired through associations, the way and the circumstances in which it has been used (Perrine \& Arp, 1992). The word "home", for example, by denotation means "a place where one lives", but by connotation means family, love, security, etc. very often the connotative meanings of words

This variety of denotations and tones of connotations make the words, and thus the language, of literature difficult to understand. Poets and story or drama writers, however, take advantage of this multidimensional language as a source of richness of meanings in their literary works.

\section{Conclusion}

In short, meanings in literary use are of two kinds: the total meaning and prose meaning. Words in literature have both denotation and connotation meanings. Language in literature is multi-dimensional and is characterized by its multiplicity of meanings. $\square$

\section{BIBLIOGRAPHY}

Bolinger, D. \& Sears, D.A. 1981. Aspects of Language. USA: Harcourt Brace Jovanovich, Inc.

Cooper, David E. 1973. Philosophy and the Nature of Language. England: Longman Group Ltd.

Millan, M. \& Hill, McGraw. 1993. Teacher's Read Aloud Anthology. NewYork: MacMillan/McGraw-Hill School Publishing Company.

Perrine, L. \& Arp, Thomas R. 1992. Sound and Sense. USA: Harcourt BraceJovanovich, Inc. 
